\title{
Relationships among rotational and conventional grazing systems, stream channels, and macroinvertebrates
}

\author{
Kara L. Raymond • Bruce Vondracek
}

Received: 18 June 2010/Revised: 20 January 2011/Accepted: 26 February 2011/Published online: 9 March 2011

(C) Springer Science+Business Media B.V. (outside the USA) 2011

\begin{abstract}
Cattle grazing in riparian areas can reduce water quality, alter stream channel characteristics, and alter fish and macroinvertebrate assemblage structure. The U.S. Department of Agriculture, Natural Resources Conservation Services has recommended Rotational Grazing (RG) as an alternative management method on livestock and dairy operations to protect riparian areas and water quality. We evaluated 13 stream channel characteristics, benthic macroinvertebrate larvae (BML), and chironomid pupal exuviae (CPE) from 18 sites in the Upper Midwest of the United States in relation to RG and conventional grazing (CG). A Biotic Composite Score comprised of several macroinvertebrate metrics was
\end{abstract}

Handling editor: Nicholas R. Bond

The Unit is jointly sponsored by the U.S. Geological Survey, the University of Minnesota, the Minnesota Department of Natural Resources, the Wildlife Management Institute, and the U.S. Fish and Wildlife Service.

K. L. Raymond ( $₫)$

National Park Service, Sonoran Desert Network,

7660 E. Broadway Blvd, Suite 308, Tucson,

AZ 85710, USA

e-mail: kara_raymond@nps.gov

B. Vondracek

U.S. Geological Survey, Minnesota Cooperative Fish and Wildlife Research Unit, University of Minnesota, 1980 Folwell Ave, St. Paul, MN 55108, USA developed for both the BML assemblage and the CPE assemblage. Multi-Response Permutation Procedures (MRPP) indicated a significant difference in stream channel characteristics between RG and CG. Nonmetric Multidimensional Scaling indicated that RG sites were associated with more stable stream banks, higher quality aquatic habitat, lower soil compaction, and larger particles in the streambed. However, neither MRPP nor Mann-Whitney $U$ tests demonstrated a difference in Biotic Composite Scores for BML or $\mathrm{CPE}$ along RG and CG sites. The BML and CPE metrics were significantly correlated, indicating that they were likely responding to similar variables among the study sites. Although stream channel characteristics appeared to respond to grazing management, BML and $\mathrm{CPE}$ may have responded to land use throughout the watershed, as well as local land use.

Keywords Bank stability · Grazing management · Chironomid pupal exuvia $\cdot$ Benthic macroinvertebrate

\section{Introduction}

Grazing animals can transform the landscape by removing riparian vegetation, compacting the soil, and trampling the stream bank (Trimble \& Mendel, 1995). Intensive grazing pressure can influence 
stream habitat and water quality by increasing erosion rates, sediment input, delivery of nutrients, bacterial and fecal material, and decreasing shade along the stream (Meehan \& Platts, 1978; Kauffman et al., 1983; Trimble \& Mendel, 1995; Knapp \& Matthews, 1996; Owens et al., 1996; Belsky et al., 1999).

Continuous grazing systems (CG) are the most common form of livestock grazing. In CG, cattle are allowed access to a pasture for the duration of the growing season. Vegetated riparian buffers and exclusion fencing are commonly implemented as best management practices (BMPs) to mitigate the effects of CG. The effectiveness of buffer strips to improve water quality through increased infiltration and reduced cattle access to the stream has been demonstrated (Beeson \& Doyle, 1995, Nerbonne \& Vondracek, 2001; Tate et al., 2006). However, researchers have recognized the implementation limitations of the current practices for buffers and are evaluating alternatives (Stonehouse, 1999; Barden et al., 2003). Researchers and managers have suggested rotational grazing (RG) as an alternative management system for livestock and dairy operations (Undersander et al., 1993; Scrimgeour \& Kendall, 2003; NRCS, 2005). Rotational grazing is considered a conservation strategy by the Natural Resources Conservation Service (NRCS, 2005), because RG requires a management change on the whole farm and often incorporates other BMPs, such as exclusion fencing and alternative water sources.

Rotational grazing is a multifunctional system that manages land to produce commodities, such as meat and milk, and non-commodity benefits, such as improved water quality and increased wildlife habitat (Boody et al., 2005). Rotational grazing systems manage pastures by rotating a grazing herd through a series of small paddocks, which allows the pasture a period for vegetation to regrow. The stocking density and grazing period in each paddock is often set to maintain a minimal height of vegetation. Although supplementary food may be provided during periods of drought, a RG dairy herd obtains a majority of its food from the pasture.

Rotational grazing systems differ from CG systems in that they are managed to maintain a minimal forage height, which should prevent overgrazing, and $\mathrm{RG}$ reduces the temporal and spatial access of cattle to the riparian area. Studies have indicated RG can be associated with improved water quality through reduced runoff, stream bank erosion, sediment inputs, turbidity, embeddedness, organic pollution, and nutrient inputs compared to CG (Olness et al., 1975; Sovell et al., 2000; Bishop et al., 2005; Zaimes et al., 2008). Haan et al. (2006) found that RG did not contribute more sediment or phosphorus than ungrazed grassland, and significantly less than CG pastures. Rotationally grazed pastures were associated with significantly less fine substrate and bank erosion than CG pastures (Lyons et al., 2000; Weigel et al., 2000). Magner et al. (2008) found riparian areas that were not grazed were associated with reduced soil compaction and greater bank stability, whereas CG sites were associated with increased soil compaction and lower bank stability; short-duration grazing sites experienced an intermediate impact.

Improved habitat quality at RG sites is expected to result in increased biotic integrity; however, studies have demonstrated inconsistent results. Weigel et al. (2000) found increased macroinvertebrate biotic integrity along RG sites. Magner et al. (2008) found that macroinvertebrate Index of Biological Integrity (IBI) scores were distributed along a gradient of riparian management; low IBI scores were associated with CG sites, high scores with nongrazed sites, whereas intermediate scores were associated with RG sites. However, Lyons et al. (2000) found no effect of RG relative to CG on fish IBI scores. The effects of RG and CG on the environment differ, but more research is needed to determine whether $R G$ is a beneficial system of land management in regard to water quality and aquatic ecosystems.

The goal of this study was to provide a comparative field study of the physical and biological characteristics along RG managed pastures in the absence of BMPs, such as exclusion fencing and riparian buffers, on adjacent stream channels. This study had two objectives: (1) evaluate stream channels characteristics and grazing density along RG pastures compared to CG pastures, and (2) evaluate macroinvertebrate composition and biotic integrity in streams along RG compared to CG pastures using benthic macroinvertebrate communities as a surrogate measurement of water quality in agricultural landscapes. We expected differences to be observed in stream channel characteristics and macroinvertebrate assemblage between RG and CG streams. Overall, RG sites were expected to have greater bank 
stability, less bank erosion, larger substrate sizes, fewer fines, reduced embeddedness, and less soil compaction than stream channels along CG sites. Streams adjacent to RG pastures were expected to have greater taxa diversity, particularly within orders Ephemeroptera, Plecoptera, and Trichoptera (EPT), and more sediment and pollution intolerant taxa than streams adjacent to CG pastures.

\section{Materials and methods}

Study sites

We identified potential dairy farms adjacent to streams from the Wisconsin Dairy Producer List in county plat books for our study. One hundred and forty-two potential dairy farms were contacted via letter followed by a telephone call. Grazing specialists in southwest Wisconsin assisted in locating RG dairy farms in Wisconsin and Iowa. Two RG dairy farms in Minnesota that had participated in a previous study by Magner et al. (2008) that compared RG and CG management were also included. Ultimately, 18 sites on 9 RG and 9 CG dairy farms in the Driftless Area Ecoregion of the United States (Omernik \& Gallant, 1988) were selected for this study: 15 in southwest Wisconsin, 2 in southeast Minnesota and 1 in northeast Iowa (Fig. 1). Grazing management had been in place for $\geq 15$ years for all study sites. All RG sites moved their cows to a fresh paddock every 12-24 h, common for RG dairies in the region. The number of paddocks per site ranged from 10 to 24 , with an average return interval of 3 weeks. Study sites without fenced riparian buffers were selected; cows at all study sites had access to the riparian area and stream channel. Two CG sites (2 and 3) had sections of the stream where the bank was stabilized by rip-rap installation within the past 10 years. Each site was visited once between 24 May and 24 June 2008.

The drainage area above each site was delineated from digital elevation maps using ArcGIS. The percent land use in the drainage basins was calculated using ArcGIS. The drainage basin of CG sites ranged from 0.2 to $52.4 \mathrm{~km}^{2}$ with mean percent land use of $25.5 \%$ pasture, $27.6 \%$ crops, $40.8 \%$ wooded, $5.8 \%$ urban, and $0.2 \%$ water. The drainage basin of RG sites ranged from 2.2 to $181.0 \mathrm{~km}^{2}$ with mean percent land use of $17.5 \%$ pasture, $46.9 \%$ crops, $26.7 \%$ wooded, $8.9 \%$ urban, and $0.2 \%$ water. The stocking rate (where a $\mathrm{AU}=$ one $455 \mathrm{~kg}$ animal) at CG sites ranged from 0.3 to $4.8 \mathrm{AU} / \mathrm{ha}$, and $\mathrm{RG}$ sites ranged from 0.2 to $4.7 \mathrm{AU} / \mathrm{ha}$.

\section{Channel characteristics}

Channel characteristics were assessed for stream reaches located at the downstream end of the grazed area at each site. Length of the stream reach was defined by the mean stream width multiplied by 35 , following the protocol of Simonson et al. (1994), with a minimum reach length of $150 \mathrm{~m}$. Reach lengths ranged from 150 to $650 \mathrm{~m}$.

Thirteen channel characteristics were measured for analysis (Table 1). Eight measurements were taken along 10 equally spaced transects following a modified protocol from Simonson et al. (1994). Measurements
Fig. 1 Study site locations and upstream drainage basin. Sites 1-9 were continuous grazing sites, and sites $10-18$ were rotational grazing sites

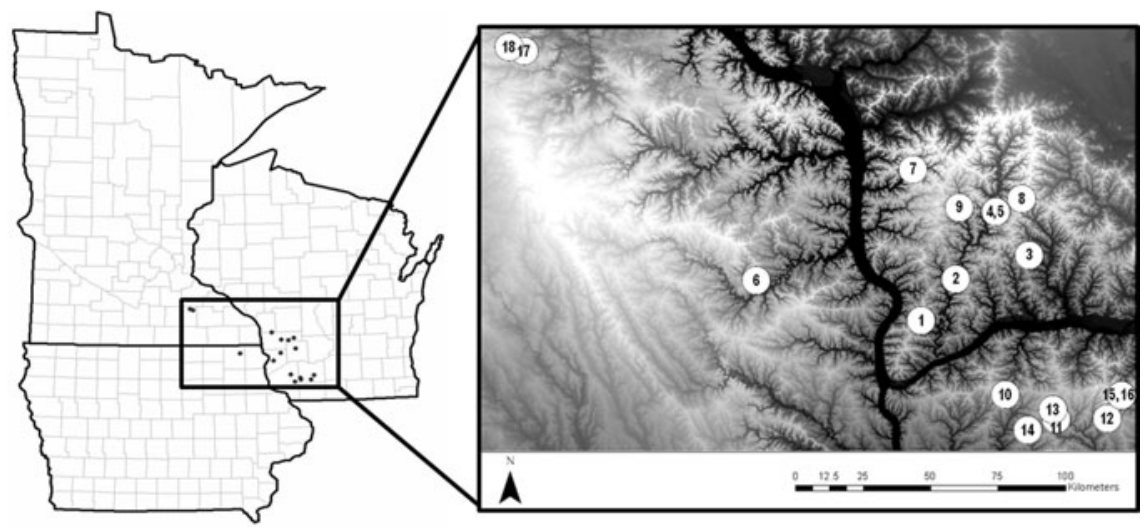




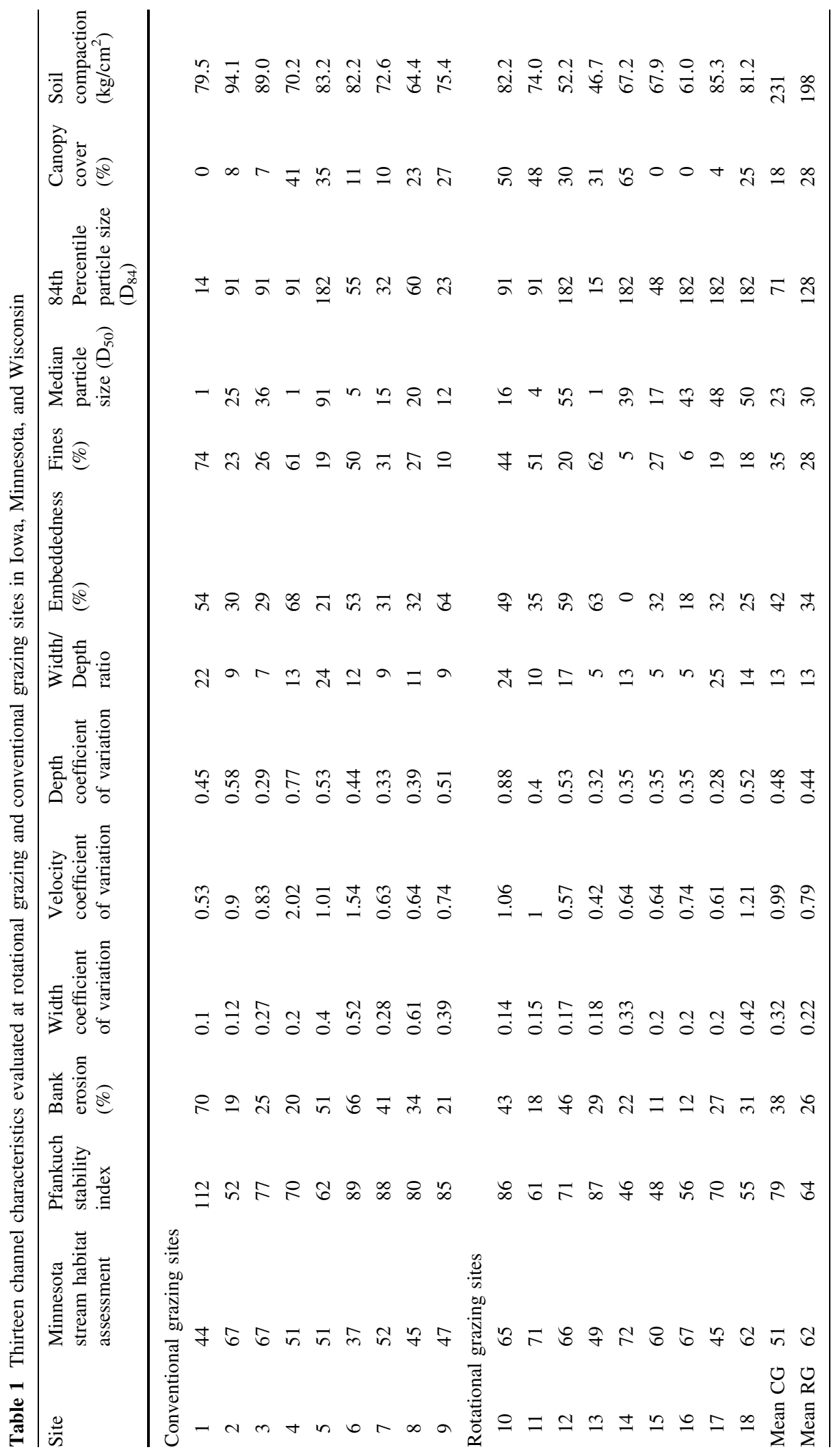


included velocity, wetted width, depth, bank erosion, embeddedness, canopy cover, and soil compaction. Stream depth and velocity were measured at 5 points along each transect using a Marsh-McBirney FloMate $^{\mathrm{TM}}$ flow meter and a graduated wading rod. We calculated a wetted width/depth ratio for the stream channel. The coefficient of variation (CV) was calculated for width, depth, and velocity at each study site for data analysis. Percent bank erosion was visually estimated to the nearest $10 \%$ of bare soil within $\pm 0.5 \mathrm{~m}$ of the transect extending up the streambank. Percent embeddedness was visually estimated to the nearest $10 \%$ for 10 particles randomly selected along each transect. Canopy cover was estimated to the nearest $10 \%$ of each transect in shade when the sun was directly overhead. Riparian soil compaction was measured $1 \mathrm{~m}$ from the stream bank on either side of the stream at depths of 7.6, 15.2, 22.9, 30.5, and $38.1 \mathrm{~cm}$, using a Dickey John ${ }^{\circledR}$ soil compaction tester at each transect. The mean values for all measurement over the 10 transects were calculated for each stream reach.

A modified Wolman pebble count was conducted at each site, following a zigzag pattern throughout the stream reach (Bevenger \& King, 1995). The diameter of the intermediate axis of 200 pebbles was estimated to $\pm 1 \mathrm{~mm}$ for diameters $<64 \mathrm{~mm}$ and by size class for diameters $\geq 64 \mathrm{~mm}$. The pebble count was used to calculate percent fines $\leq 6.4 \mathrm{~mm}$, median particle size $\left(D_{50}\right)$, and the particle size of the 84 th percentile $\left(\mathrm{D}_{84}\right)$.

Two qualitative indices were conducted in each study reach to evaluate bank stability and aquatic habitat quality: the Pfankuch Stability Index (PSI) (Pfankuch, 1975) and Minnesota Pollution Control Agency's Stream Habitat Assessment (MSHA) (MPCA, 2007). The MSHA is modified from the Ohio Qualitative Habitat Evaluation Index (Rankin, 1989).

\section{Benthic macroinvertebrate communities}

Previous studies that have evaluated macroinvertebrates in relation to grazing have only collected benthic macroinvertebrate larvae (BML). In this study, in addition to benthic macroinvertebrates, we identified chironomid pupal exuviae (CPE). The collection of $\mathrm{CPE}$ is a cost-effective alternative biomonitoring method because CPE are simple to collect, more easily identified than larval chironomids, and chironomids alone may be as informative for bioassessment as using a larger group of taxa (Ferrington et al., 1991). Chironomid pupal exuviae have been useful in assessing the impact of point sources of sewage and heavy metals (Coler, 1984; Ferrington \& Crisp, 1989; Hayford \& Ferrington, 2005). Thus, Chironomidae may also be as or more sensitive to local agricultural land use as other benthic macroinvertebrates.

Benthic invertebrates were sampled from all sites within a month to reduce seasonal effects on the benthic communities. Samples were collected using a modified Hess sampler (surface area, $0.086 \mathrm{~m}^{2}$; mesh size $500 \mu \mathrm{m}$ ). Three samples were collected from riffles in the downstream portion of each study reach, except sites 4 and 6 where two samples were collected. The BML were only collected in riffles rather than multiple habitats, because riffles tend to be more sensitive to disturbance gradients than multiple habitat samples or other single habitat samples (Blocksom et al., 2008). Samples were preserved in $70 \%$ ethanol. Each sample was subsampled in the laboratory to 300 specimens or until all specimens in the sample had been sorted (Hilsenhoff, 1987). Thus, up to 900 specimens were identified at each site. Insect larvae, except Chironomidae, were identified to genus using Merritt \& Cummins (1996). Non-insect taxa were identified to family or order.

A single qualitative CPE sample was collected at each study site. In streams $<10 \mathrm{~m}$ wide, most pupal exuviae drift less than $100 \mathrm{~m}$ from their emergence site before entering an eddy (Wilson \& Bright, 1973), but low numbers of exuviae can drift up to $250 \mathrm{~m}$ downstream from their site of emergence (Wilson \& Ruse, 2005). CPE samples were collected in the downstream end of each site following the protocol of Ferrington et al. (1991) to guarantee that most of the specimens originated from the study reach. Collection was focused along stream edges and in eddies where foam, debris, and exuviae accumulate. Floating exuviae were collected for a $10 \mathrm{~min}$ period by dipping the edge of a pan $(30 \mathrm{~cm} \times 22.5 \mathrm{~cm} \times$ $5 \mathrm{~cm}$ ) beneath the water surface, allowing water, exuviae, and debris to flow into the pan. The contents of the pan were poured through a $125 \mu \mathrm{m}$ sieve. This process was rapidly repeated during the collection period, starting at the farthest downstream area and continuing upstream, on average a $50 \mathrm{~m}$ length of the 
channel was sampled. Each sample was subsampled to 150 specimens. Less than $150 \mathrm{CPE}$ specimens were collected from two sites likely due to high discharge prior to sampling. These two sites were excluded and analysis of CPE was performed on the remaining 16 sites. Chironomid pupal exuviae specimens were identified under the dissecting scope to genus using Wiederholm (1986). Three specimens from each genus from each sample were individually mounted in Euparal ${ }^{\circledR}$ on microscope slides to verify identification.

Biotic composite scores

Biotic composite scores (BCS) comprised of several macroinvertebrate metrics were developed for both the BML assemblage and the CPE assemblage. Biotic composite scores provided a narrative assessment of water quality to compare the two grazing types. Metrics for BML samples (Table 2) included taxa number, percent dominance of the three most abundant taxa (percent dominance-3 taxa), Hilsenhoff Biotic Index, percent Chironomidae, percent Ephemeroptera, percent Coleoptera, percent predators, and percent depositional (Hilsenhoff, 1987; Barbour et al.,
1992; Kerans \& Karr, 1994; DeShon, 1995; Fore et al., 1996; Barbour et al., 1999; Karr \& Chu, 1999, p. 76; Zweig \& Rabeni, 2001; Braccia \& Voshell, 2006, 2007). Metrics for the CPE samples (Table 3) included taxa number, percent dominant- 3 taxa, Hilsenhoff biotic index, percent intolerant, percent Tanytarsini, percent Orthocladiinae, and percent burrower (DeShon, 1995; Angradi, 1999; Kosinicki $\&$ Sites, 2007).

Metric values were assigned unitless scores: 5, 3, and 1 (Tables 2,3). Division between scores was set at the 1st and 3rd quartile for each metric (Karr et al., 1986). For metrics with a negative response to increasing disturbance, a 5 was assigned to values $\geq 3$ rd quartile, indicating relatively good quality. A score of 3 was assigned to metric values between the 1 st and 3rd quartile, and a score of 1 was assigned to metrics $\leq 1$ st quartile. Metrics with a positive relationship to increasing disturbance were assigned scores in reverse order. Scores of the metrics for each site were summed, to generate the BCS. The maximum BML BCS was 45 and the maximum CPE biotic index score was 35 . A BCS was calculated for each BML sample, and the mean BCS was calculated for each site.

Table 2 Metrics for benthic macroinvertebrate larvae (BML), the predicted response, reference, and score for each metric

\begin{tabular}{|c|c|c|c|c|c|c|}
\hline \multirow[t]{2}{*}{ Metric } & \multirow[t]{2}{*}{ Metric driver } & \multirow{2}{*}{$\begin{array}{l}\text { Response to } \\
\text { overgrazing }\end{array}$} & \multirow[t]{2}{*}{ Reference } & \multicolumn{3}{|l|}{ Score } \\
\hline & & & & 1 & 3 & 5 \\
\hline Taxa number & $\begin{array}{l}\text { Habitat homogenity, } \\
\text { sedimentation }\end{array}$ & Decrease & $\begin{array}{l}\text { Barbour et al. (1992), Barbour } \\
\text { et al. (1999), } \\
\text { Karr \& Chu (1999), (2001) }\end{array}$ & $\leq 5.8$ & $>5.8$ and $<11.0$ & $\geq 11.0$ \\
\hline Percent dominance- 3 taxa & Disturbance & Increase & $\begin{array}{c}\text { Barbour et al. (1999), } \\
\text { Karr \& Chu (1999) }\end{array}$ & $\geq 94.6$ & $<94.6$ and $>80.6$ & $\leq 80.6$ \\
\hline HBI & Disturbance & Increase & $\begin{array}{l}\text { Fore et al. (1996), } \\
\text { Karr \& Chu (1999) }\end{array}$ & $\geq 5.0$ & $<5.0$ and $>4.6$ & $\leq 4.6$ \\
\hline Percent Chironomidae & $\begin{array}{l}\text { Disturbance } \\
\text { Sedimentation }\end{array}$ & Decrease & $\begin{array}{l}\text { Karr \& Chu (1999), } \\
\text { Zweig \& Rabeni (2001) }\end{array}$ & $\geq 52.3$ & $<52.3$ and $>12.9$ & $\leq 12.9$ \\
\hline Percent EPT & Disturbance & Decrease & Fore et al. (1996) & $\leq 13.5$ & $>13.5$ and $<52.3$ & $\geq 52.3$ \\
\hline $\begin{array}{l}\text { Percent } \\
\text { Ephemeroptera }\end{array}$ & $\begin{array}{l}\text { Organic pollution, } \\
\text { dissolved oxygen }\end{array}$ & Increase & $\begin{array}{l}\text { Hilsenhoff (1987), } \\
\text { Barbour et al. (1992), } \\
\text { Kosinicki \& Sites (2007) }\end{array}$ & $\leq 7.9$ & $>7.9$ and $<43.5$ & $\geq 43.5$ \\
\hline Percent Coleoptera & Sedimentation & Increase & Fore et al. (1996) & $\leq 0.3$ & $>0.3$ and $<11.2$ & $\geq 11.2$ \\
\hline Percent predator & $\begin{array}{l}\text { Trophic relationships, } \\
\text { disturbance }\end{array}$ & Decrease & $\begin{array}{l}\text { Kerans \& Karr (1994), } \\
\text { Karr \& Chu (1999) }\end{array}$ & 0 & $>0$ and $<2.6$ & $\geq 2.6$ \\
\hline Percent depositional & Sedimentation & Decrease & $\begin{array}{l}\text { Braccia \& Voshell (2006), } \\
\text { Braccia \& Voshell (2007) }\end{array}$ & $\geq 92.5$ & $>64.7$ and $>64.7$ & $\leq 64.7$ \\
\hline
\end{tabular}

Division between scores was set at the 1 st and 3rd quartile for each metric 
Table 3 Metrics for chironomid pupal exuvia (CPE), the predicted response, reference, and score for each metric

\begin{tabular}{|c|c|c|c|c|c|c|}
\hline \multirow[t]{2}{*}{ Metric } & \multirow[t]{2}{*}{ Metric driver } & \multirow{2}{*}{$\begin{array}{l}\text { Response to } \\
\text { overgrazing }\end{array}$} & \multirow[t]{2}{*}{ Reference } & \multicolumn{3}{|l|}{ Score } \\
\hline & & & & 1 & 3 & 5 \\
\hline Taxa number & $\begin{array}{l}\text { Habitat homogenity, } \\
\text { sedimentation }\end{array}$ & Decrease & $\begin{array}{l}\text { Barbour et al. (1992), } \\
\text { Zweig \& Rabeni (2001) }\end{array}$ & $\leq 9.0$ & $>9.0$ and $<13.5$ & $\geq 13.5$ \\
\hline $\begin{array}{l}\text { Percent dominance-3 } \\
\text { taxa }\end{array}$ & Disturbance & & $\begin{array}{l}\text { Barbour et al. (1999), } \\
\text { Karr \& Chu (1999) }\end{array}$ & $\geq 87.3$ & $<87.3$ and $>71.0$ & $\leq 71.0$ \\
\hline HBI & $\begin{array}{l}\text { Disturbance biological } \\
\text { oxygen demand }\end{array}$ & Increase & $\begin{array}{c}\text { Barbour et al. (1999), } \\
\text { Karr \& Chu (1999) }\end{array}$ & $\geq 6.9$ & $<6.9$ and $>6.3$ & $\leq 6.3$ \\
\hline Percent Intolerant & Sediment & Decrease & $\begin{array}{l}\text { Deshon (1995), Kosinicki } \\
\text { \& Sites (2007) }\end{array}$ & $\leq 4.5$ & $>4.5$ and $<33.5$ & $\geq 33.5$ \\
\hline Percent Tanytarsini & $\begin{array}{l}\text { Organic pollution, } \\
\text { dissolved oxygen }\end{array}$ & Increase & Angradi (1999) & $\leq 3.6$ & $>3.6$ and $<14.3$ & $\geq 14.3$ \\
\hline Percent Orthocladiinae & $\begin{array}{l}\text { Organic pollution, } \\
\text { dissolved oxygen }\end{array}$ & Increase & $\begin{array}{l}\text { Barbour et al. (1992), } \\
\text { Hilsenhoff (1987), } \\
\text { Kosinicki \& Sites (2007) }\end{array}$ & $\geq 94.0$ & $<94.0$ and $>63.7$ & $\leq 63.7$ \\
\hline Percent Burrower & Sedimentation & Decrease & Fore et al. (1996) & $\geq 14.7$ & $<14.7$ and $>3.7$ & $\leq 3.7$ \\
\hline
\end{tabular}

Division between scores was set at the 1 st and 3rd quartile for each metric

Data analysis

A Multi-Response Permutation Procedure (MRPP) with Sorenson's distance measure was used to compare watershed and channel characteristics, Biotic composite scores for BML, CPE, and combined BML, and $\mathrm{CPE}$ assemblage composition between grazing types using PC-ORD version 5 (McCune \& Mefford, 1999). MRPP is a non-parametric procedure that does not require assumptions of normality or variance (McCune \& Grace, 2002). MRPP can address similar questions as a Multivariate Analysis of Variance to compare two or more pre-existing groups of variables. For analysis of the watershed characteristics, drainage area was $\log _{10}$ transformed and all land use variables were converted to proportions and arcsine square-root transformed. For analysis of the stream channel characteristics, embeddedness, bank erosion, canopy cover, and percent fines were converted to proportions and arcsine square-root transformed and width/depth ratio, $\mathrm{D}_{50}, \mathrm{D}_{84}$, MSHA, PSI, and soil compaction were $\log _{10}$ transformed. Values for BML, CPE, and combined BML and CPE assemblage composition were $\log _{10}$ transformed.

One-sided Mann-Whitney $U$ tests using Statistica (StatSoft, Inc., 2009) were performed to compare stocking rate (AU/ha) of pasture and stocking rate per length stream $(\mathrm{AU} / \mathrm{ha} / \mathrm{km})$; where a $\mathrm{AU}=$ one $455 \mathrm{~kg}$ animal (Holechek et al., 2001) between the grazing types and on the BCS of both assemblages to compare the water quality between the two grazing types. Mann-Whitney $U$ tests were considered significant at $P \leq 0.05$. Pearson correlation analyses were performed to evaluate; (1) the relationship between the stocking rate and each channel characteristic separately, (2) the stocking rate per length of stream and each channel characteristic separately, (3) the relationship between the BML and CPE BCS, (4) the relationship between the metrics of community structure for the BML and CPE with each channel characteristic, and (5) the relationship between the metrics of community structure for the BML and CPE with stocking rate. The Pearson correlations were considered significant at $P \leq 0.05$.

Nonmetric multidimensional scaling (NMS) with PC-ORD version 5 (McCune \& Mefford, 1999) with Sorenson's distance measure was used to ordinate stream channel characteristics. Nonmetric multidimensional scaling does not assume linear relationships among variables (McCune \& Grace, 2002). Nonmetric multidimensional scaling calculates the stress of the ordination or the optimality of the solution. A final stress $<10$ indicates little risk in making inferences, whereas interpretation of an ordination with a final stress $>10$ may be misleading (Clarke, 1993). Real data were run 50 times and a Monte Carlo simulation (a standard option in PC-ORD version 5) was completed with 50 runs of randomized data to evaluate the 


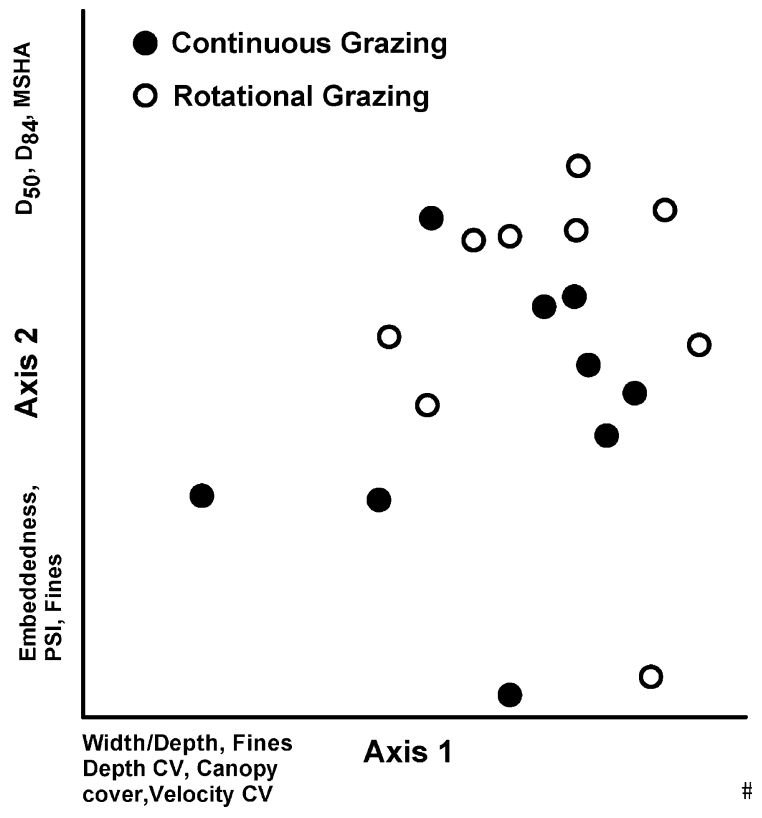

Fig. 2 Nonmetric multidimensional scaling ordination of 13 stream channel characteristics for 18 stream sites. Numbers indicate site number in Table 1. Final stress $=9.57$, final instability $<0.00001$, and number of iterations $=54$

probability that a similar final stress could be obtained by chance. A random starting configuration was used. The NMS used the 13 channel characteristics with embeddedness, bank erosion, canopy cover, and percent fines converted to proportions and arcsine square-root transformed (Table 1). Soil compaction, $\mathrm{D}_{50} \mathrm{D}_{84}, \mathrm{MSHA}$, and PSI were $\log _{10}$ transformed. Following the ordination, channel characteristics were correlated with both axes using a Pearson correlation and Kendall's rank correlation $(P=0.05)$. Stocking rate and stocking rate per length stream were correlated with both axes of the NMS of the channel characteristics using a Pearson correlation and Kendall's rank correlation $(P=0.05)$.

\section{Results}

Drainage area and watershed land use were not significantly different across grazing types $(A=-0.005$, $T=0.177, P=0.474$, MRPP). However, stocking rates of the 18 sites ranged from 0.2 to $4.8 \mathrm{AU} / \mathrm{ha}$ or 0.1 to $7.7 \mathrm{AU} / \mathrm{ha} / \mathrm{stream}$ length and were significantly different $(P=0.050$ and 0.019 , respectively; MannWhitney $U$ test). Only the $\mathrm{CV}$ of velocity $(P=0.013$ and 0.012, Mann-Whitney $U$ test) and percent fines $(P=0.019$ and 0.010 , Mann-Whitney $U$ test $)$ in the stream channels were correlated with AU/ha and AU/ha/stream length. The relationships were positive, thus the $\mathrm{CV}$ of velocity and percent fines increased with higher stocking rates.

Channel characteristics were significantly different between grazing types $(A=0.067, T=-1.996$, $P=0.050$, MRPP). The 13 physical channel variables explained $15.3 \%$ of the variance along axis 1 and $78.8 \%$ along the second axis in a two-dimensional NMS after 54 iterations (Fig. 2). Final stress was 9.57 and instability was $<0.00001$. CV of Velocity, CV of Depth, width/depth ratio, and canopy cover were significantly and negatively correlated with the first axis of the NMS (Table 4). $\mathrm{D}_{50}, \mathrm{D}_{84}$, and MSHA were significantly and positively correlated with the second axis of the NMS, whereas percent fines and embeddedness were significantly and negatively correlated with the second axis of the NMS. Neither measure of stocking rate was correlated with the first or second axes of the NMS $(r<0.270)$.

A total of 104 taxa was collected; 68 taxa were collected from BML samples, dominated by Chironomidae, Baetis, and Simulium. The number of taxa ranged from 6 to 20 at BML sites. Thirty-six genera of CPE were collected, dominated by Eukiefferiella, Cricotopus, and Micropsectra. The number of taxa ranged from 4 to 18 taxa for CPE samples. We found no significant difference between grazing management for BML $(A=0.004, T=-0.310, P=0.329$, MRPP), CPE $(A=-0.002, T=0.103, P=0.480$, MRPP), or BML and CPE combined $(A=0.002$, $T=-0.221, P=0.365$, MRPP).

The range of BCS for BML samples was 19.7-35.0 and the range of BCS for CPE samples was 11-29. The mean BML BCS for CG was 26.6 and the mean score for RG was 27.4. The mean score for the CG BCS for CPE was 19.9 and the mean for RG was 22.0. The BCS for BML and CPE were not significantly different between $\mathrm{CG}$ and $\mathrm{RG}$ sites $(\mathrm{BML}=0.875, \mathrm{CPE}=$ 0.318 , Mann-Whitney $U$ test). There were no relationships with stocking rate (AU/ha or $\mathrm{AU} / \mathrm{ha} / \mathrm{km})$ or Fines with metrics of community structure for riffle larvae; however, Coleoptera were correlated with PSI $(r=-0.519, P=0.028)$ and embeddedness $(r=$ $-0.543, P=0.020)$ and percent dominant-3 taxa was correlated with bank erosion $(r=0.503$, $P=0.034)$; channel characteristics which are affected 
Table 4 Pearson and Kendall's rank correlations with the NMS ordination axes for channel characteristics

\begin{tabular}{|c|c|c|c|c|c|c|}
\hline \multirow[t]{2}{*}{ Axis } & \multicolumn{3}{|l|}{1} & \multicolumn{3}{|l|}{2} \\
\hline & $r$ & $r^{2}$ & $\tau$ & $r$ & $r^{2}$ & $\tau$ \\
\hline $\mathrm{D}_{50}$ & 0.309 & 0.095 & 0.013 & 0.933 & 0.87 & 0.766 \\
\hline$\%$ Fines & -0.457 & 0.209 & -0.021 & $-\mathbf{0 . 8 5 2}$ & 0.726 & -0.721 \\
\hline $\mathrm{D}_{84}$ & -0.237 & 0.056 & -0.157 & 0.883 & 0.78 & 0.757 \\
\hline Velocity CV & -0.861 & 0.742 & -0.529 & -0.052 & 0.003 & 0.007 \\
\hline Embeddedness & -0.325 & 0.105 & -0.163 & -0.686 & 0.47 & -0.621 \\
\hline Depth CV & -0.719 & 0.517 & -0.464 & -0.045 & 0.002 & -0.059 \\
\hline PSI & -0.147 & 0.022 & -0.066 & -0.7 & 0.49 & -0.525 \\
\hline Width/Depth & -0.559 & 0.312 & -0.477 & 0.127 & 0.016 & 0.137 \\
\hline MSHA & 0.131 & 0.017 & 0.092 & 0.556 & 0.309 & 0.446 \\
\hline Canopy cover & -0.471 & 0.222 & -0.356 & 0.133 & 0.018 & 0.013 \\
\hline Bank erosion & -0.33 & 0.109 & -0.281 & -0.36 & 0.13 & -0.111 \\
\hline Soil compaction & -0.307 & 0.094 & -0.294 & 0.197 & 0.039 & 0.033 \\
\hline
\end{tabular}

Values in bold are significant at $P<0.05$

by grazing. Intolerant taxa $(r=-0.655, P=0.005)$ and HBI $(r=0.659, P=0.006)$, metrics of community structure for $\mathrm{CPE}$, were correlated with soil compaction, and Tanytarsini were correlated with stocking rate (AU/ha; $r=0.530, P=0.031)$ and stocking rate per stream length $(\mathrm{AU} / \mathrm{ha} / \mathrm{km} ; r=$ $0.576, P=0.022)$. The BML and CPE BCS were significantly correlated $(r=0.781, P<0.001)$ (Fig. 3).

\section{Discussion}

We found a significant difference in the stream channel characteristics and habitat between RG and CG sites. Pastures managed by RG indicated a reduced impact of cattle at the local reach scale, which included greater streambank stability, larger substrate size in the streambed, and overall greater habitat quality. However, we found no difference in the macroinvertebrate assemblages between the two grazing types. The lack of difference in the macroinvertebrate assemblage between management types is similar to a study of stream reaches with and without livestock exclusion to the riparian area (Ranganath et al., 2009). There may be two reasons why the macroinvertebrate assemblages may not have been different between RG and CG; (1) the macroinvertebrate assemblage may have responded to land use at a scale greater than the study reach, and (2) the differences of the channel variables between the two

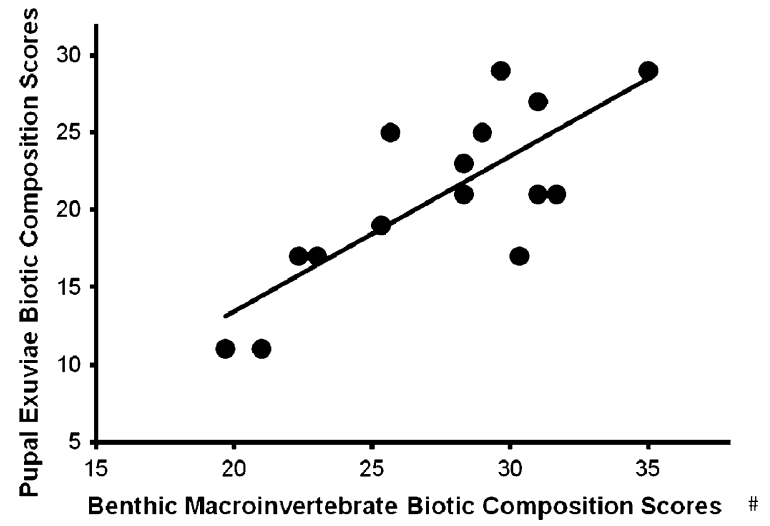

Fig. 3 Relationship of the mean benthic macroinvertebrate biotic composite scores with chironomid pupal exuviae biotic composite scores

grazing types may have been statistically different, but not ecologically different enough to effect a change in the macroinvertebrate assemblage.

The underlying assumption in this study was that the management of grazed pastures at the local scale would be the most influential factor affecting channel characteristics and the macroinvertebrate assemblages. We found that the stocking rate was correlated with the $\mathrm{CV}$ of velocity and the percent fines in the streambed. The positive relationship with percent fines is consistent with increased cattle activity on the streambanks (Trimble \& Mendel, 1995), which may have decreased infiltration and increased the delivery 
of fine sediment into the streambed. Thus, there was an effect of grazing at the local scale.

There has been significant discussion in the literature about the scale at which benthic macroinvertebrate assemblages are influenced; land use and land cover at the local reach (Sponseller et al., 2001), land use and land cover along the riparian corridor (Rios \& Bailey, 2006), or land use and geology throughout an entire watershed (Richards et al., 1996), or land use both adjacent to the stream and throughout the catchment (Vondracek et al., 2005). Although stream channel characteristics were significantly different along our study sites, these sites existed in watersheds where other land uses upstream may have affected the water quality, stream channel characteristics, and the macroinvertebrate assemblage in the study reaches.

We evaluated stream reaches on individual farms and did not evaluate the extent of grazing practices or BMPs at the watershed scale. Wang et al. (2002) found that a watershed with widespread riparian and upland BMPs had higher overall stream habitat quality, bank stability, and abundance of coldwater fishes. However, a watershed with limited riparian and upland BMPs did not have similar habitat quality or bank stability. Thus, differential implementation of RG and other BMPs in the watersheds upstream of our study sites may account, in part, for the lack of response of the macroinvertebrates.

The current condition of the watersheds must also be placed into an historical context. Agricultural activities, including grazing on steep hillsides after 1850 significantly altered stream systems; however, soil conservation practices after the 1930s and the implementation of Public Law (PL) 566 in the 1950s and 1960s reduced frequent flooding and associated erosion, and increased infiltration and base flow (Thorn et al., 1997). However, Harding et al. (1998) found that watershed land use in the 1950s was a better indicator of present invertebrate and fish diversity than land use in the 1990s. While grazing management at all study sites had been in place for $\geq 15$ years, land use prior to that time may have had long-term impacts on the aquatic ecosystem.

The percent of the watershed in cropland, urban land use, and to lesser extent, pasture likely influenced the macroinvertebrate assemblage, possibly concealing a response of the macroinvertebrate assemblage to grazing management (Allan, 2004).
Macroinvertebrates and fish can be affected by low levels of urbanization in a watershed. The threshold of watershed impervious cover associated with urbanization is between 7 and 14\%, above which IBI scores are consistently poor (Wang et al., 2001; Wang \& Kanehl, 2003; Miltner et al., 2004; Stepenuck et al., 2008). The drainage area of 12 of the 18 sites had urban land cover above $7 \%$, which could have influenced the macroinvertebrate assemblage more than grazing type within the reach. Wang et al. (2001) found that agricultural land use in a watershed $>50 \%$ resulted in low IBI scores. The drainage area of 6 of 18 sites had $>50 \%$ land in row crops, which could have also influenced the macroinvertebrate assemblages, concealing a response of the macroinvertebrates to grazing type at a local scale.

The second hypothesis for the why differences in macroinvertebrate communities were not observed is that although several channel variables were statistically significant, the habitat may not have been ecologically different enough to affect the macroinvertebrate assemblages. For example, Kaller \& Hartman (2004) found macroinvertebrate diversity was reduced when fines comprised $>0.9 \%$ of the substrate mass in riffles. Even though substrate size in RG sites was significantly larger than CG sites, fines were likely not reduced below a threshold level. Cuffney et al. (2000) concluded that benthic macroinvertebrates had a threshold response to low levels of agricultural intensity.

We found support for the use of RG without additional BMPs as a conservation strategy on pastured land to increase bank stability and aquatic habitat quality. Rotational grazing is considered a conservation strategy by the Natural Resources Conservation Service (NRCS, 2005). The increased frequency of rotation in RG management and the implementation of other BMPs, including exclusion fencing and alternative water sources, are likely to further decrease the impact of grazing in the riparian area and on the stream channel (Wang et al., 2002). However, RG on a small stream reach may not result in significant changes in water quality. Although RG at the study sites was associated with increased streambank stability and larger particle sizes in the streambed, the overall land use in the watershed may have prevented improved biological integrity. Many studies have concluded that BMP implementation should be focused on longer reaches or whole watersheds (Brezonik et al., 1998; Wang et al., 2002; Vondracek et al., 2005; Ranganath 
et al., 2009). Thus, grazed lands adjacent to streams impaired for sediment or biotic integrity could be targeted for adoption of RG as part of an integrated watershed management system.

The CPE assemblage composition and BCS did not distinguish between the two grazing types. However, the BML assemblage composition and BCS, which included commonly used metrics (Hilsenhoff, 1987; Barbour et al., 1992; Kerans \& Karr, 1994; DeShon, 1995; Fore et al., 1996; Barbour et al., 1999; Karr \& Chu, 1999, p. 76; Zweig \& Rabeni, 2001; Braccia \& Voshell, 2006, 2007), also did not distinguish the grazing management types. The significant correlation between the two BCS indicated that they were likely responding to similar variables among the study sites. This study did not provide sufficient evidence to conclude that CPE could more effectively or efficiently be used to monitor degradation in agricultural watersheds; however, the use of CPE may warrant further investigation.

\section{Conclusions}

This study demonstrated a difference in overall stream channel characteristics and habitat quality between stream reaches adjacent to rotational grazing and continuous grazing management. Although there was an increase in percent fines in the streambed with increased stocking rate, rotational grazing sites had more stable streambanks, higher quality aquatic habitat, lower soil compaction, and larger particles in the streambed than conventional grazing sites. Rotational grazing is a strategy that may mitigate local bank and stream habitat degradation, and implemented over a long reach may improve the macroinvertebrate assemblage.

\footnotetext{
Acknowledgments We thank the members of the research group: Nick Jordan, Steve Manson, and Kristen Nelson for their contributions to the formation of this project. We also thank Brandon Wiarda and Sonya Ewert for their help collecting field data, Rebecca Jacobson for insect identification, Adam Berland for GIS analysis, and Leonard Ferrington Jr. for his wealth of knowledge about Chironomidae. An earlier draft of this manuscript was improved thanks to reviews by Shaun Moore, Eric Romaniszyn, and Brian Weigel. This research was funded by the National Science Foundation under the Biocomplexity in the Environment Priority Area, Award ID 0709613. Reference to trade names does not imply endorsement by authors or the U.S. Government.
}

\section{References}

Allan, J. D., 2004. Landscapes and riverscapes: the influence of land use on stream ecosystems. Annual Review of Ecology, Evolution, and Systematics 35: 257-284.

Angradi, T. R., 1999. Fine sediment and macroinvertebrate assemblages in Appalachian streams: a field experiment with biomonitoring applications. Journal of the North American Benthological Society 18: 49-66.

Barbour, M. T., J. L. Plafkin, B. P. Bradley, C. G. Graves \& R. W. Wisseman, 1992. Evaluation of EPA's rapid bioassessment benthic metrics: metric redundancy and variability among reference stream sites. Environmental Toxicology and Chemistry 11: 437-449.

Barbour, M. T., J. Gerritsen, B. D. Snyder \& J. B. Stribling, 1999. Rapid Bioassessment Protocols for Use in Streams and Wadeable Rivers: Periphyton, Benthic Macroinvertebrates and Fish, 2nd ed. EPA 841-B-99-002. U.S. Environmental Protection Agency; Office of Water, Washington, DC.

Barden, V., K. R. Mankin, D. M. Ngandu, W. A. Geyer, D. L. Devlin \& K. McVay, 2003. Assessing the Effectiveness of Various Riparian Buffer Vegetation Types. SRL 137. Kansas State University, Agricultural Experimental Station and Cooperative Extension, Manhattan.

Beeson, C. E. \& P. F. Doyle, 1995. Comparison of bank erosion at vegetated and non-vegetated channel bends. Water Resources Bulletin 31: 983-990.

Belsky, A. J., A. Matzke \& S. Uselman, 1999. Survey of livestock influences on stream and riparian ecosystems in the western United States. Journal of Soil and Water Conservation 54: 419-431.

Bevenger, G. S. \& R. M. King, 1995. A Pebble Count Procedure for Assessing Watershed Cumulative Effects. Research Paper RM-RP-319. Department of Agriculture, Forest Service, Rocky Mountain Forest and Range Experiment Station, Fort Collins, CO: US.

Bishop, P. L., W. D. Hively, J. R. Stedinger, M. R. Rafferty, J. L. Lojpersberger \& J. A. Bloomfield, 2005. Multivariate analysis of paired watershed data to evaluate agricultural best management practice effects on stream water phosphorus. Journal of Environmental Quality 34: 1087-1101.

Blocksom, K. A., B. C. Autrey, M. Passmore \& L. Reynolds, 2008. A comparison of single and multiple habitat protocols for collecting macroinvertebrates in wadeable streams. Journal of the American Water Resources Association 44: 577-593.

Boody, G., B. Vondracek, D. A. Andow, M. Krinke, J. Westra, J. Zimmerman \& P. Welle, 2005. Multifunctional agriculture in the United States. BioScience 55: 27-38.

Braccia, A. \& J. R. Voshell Jr., 2006. Environmental factors accounting for benthic macroinvertebrate assemblage structure at the sample scale in streams subjected to a gradient of cattle grazing. Hydrobiologia 573: 55-73.

Braccia, A. \& J. R. Voshell Jr, 2007. Benthic macroinvertebrate responses to increasing levels of cattle grazing in Blue Ridge Mountain streams, Virginia, USA. Environmental Monitor Assessment 131: 185-200.

Brezonik, P. L., K. W. Easter, L. Hatch, D. Mulla \& J. Perry, 1998. Management of diffuse pollution in agricultural 
watersheds: lessons from the Minnesota River basin. Water Science and Technology 39: 323-330.

Clarke, K. R., 1993. Non-parametric multivariate analyses of changes in community structure. Australian Journal of Ecology 18: 117-143.

Coler, B. G., 1984. Community responses of Chironomidae (Diptera) to organic enrichment in a small Kansas stream. Masters thesis, University of Kansas, Lawrence, Kansas: $81 \mathrm{pp}$.

Cuffney, T. F., M. R. Meador, S. D. Porter \& M. E. Gurtz, 2000. Responses of physical, chemical and biological indicators of water quality to a gradient of agricultural land use in the Yakima River basin, Washington. Environmental Monitoring and Assessment 64: 259-270.

DeShon, J. E., 1995. Development and application of the invertebrate community index (ICI). In Davis, W. S. \& T. P. Simon (eds), Biological Assessment and Criteria: Tools for Water Resource Planning and Decision Making. Lewis Publishers, Boca Raton, FL: 217-243.

Ferrington, L. C. Jr. \& N. H. Crisp, 1989. Water chemistry characteristics of receiving streams and the occurrence of Chironomus riparius and other Chironomidae in Kansas. Acta Biologica Debrecina Oecologica Hungarica 3: 115-126.

Ferrington, L. C. Jr., M. A. Blackwood, C. A. Wright, N. H. Crisp, J. L. Kavanaugh \& F. J. Schmidt, 1991. A protocol for using surface-floating pupal exuviae of Chironomidae for rapid bioassessment of changing water quality. In: Sediment and Stream Water Quality in a Changing Environment: Trends and Explanations. IAHS Publication Number 203: 181-190.

Fore, L. S., J. R. Karr \& R. W. Wisseman, 1996. Assessing invertebrate response to human activities: evaluating alternative approaches. Journal of North American Benthological Society 15: 212-231.

Haan, M. M., J. R. Russell, W. J. Powers, J. L. Kovar \& J. L. Benning, 2006. Grazing management effects on sediment and phosphorous in surface runoff. Rangeland Ecology and Management 59: 607-615.

Harding, J. S., E. F. Benfield, P. V. Bolstad, G. S. Helfman \& E. B. D. Jones III, 1998. Stream biodiversity: the ghost of land use past. Proceedings of the National Academy of Sciences of the United States of America 95: 14843-14847.

Hayford, B. L. \& L. C. Ferrington Jr., 2005. Biological assessment of Cannon Creek, Missouri by use of emerging Chironomidae (Insecta: Diptera). Journal of the Kansas Entomological Society 78: 89-99.

Hilsenhoff, W. L., 1987. An improved biotic index of organic stream pollution. The Great Lakes Entomologist 20: 31-39.

Holechek, J. L., R. D. Pieper \& C. H. Herbel, 2001. Range Management: Principles and Practices, 4th ed. Prentice Hall, New Jersey.

Kaller, M. D. \& K. J. Hartman, 2004. Evidence of a threshold level of fine sediment accumulation for altering benthic macroinvertebrate communities. Hydrobiologia 518: 95-104.

Karr, J. R. \& E. W. Chu, 1999. Restoring Life in Running Waters: Better Biological Monitoring. Island Press, Washington, DC.
Karr, J. R., K. D. Fausch, P. L. Angermeier, P. R. Yant \& I. J. Schlosser, 1986. Assessing biological integrity in running waters: a method and its rationale. Illinois Natural History Survey Special Publication 5, 28 pp.

Kauffman, J. B., W. C. Krueger \& M. Vavra, 1983. Effects of late season cattle grazing on riparian plant communities. Journal of Range Management 36: 685-691.

Kerans, B. L. \& J. R. Karr, 1994. A benthic index of biotic integrity (B-IBI) for rivers of the Tennessee Valley. Ecological Applications 4: 768-785.

Knapp, R. A. \& K. R. Matthews, 1996. Livestock grazing, golden trout \& streams in the Golden Trout Wilderness, California: impacts and management implications. North American Journal of Fisheries Management 16: 805-820.

Kosinicki, E. \& R. W. Sites, 2007. Least-desired index for assessing the effectiveness of grass riparian filter strips in improving water quality in an agricultural region. Community and Ecosystem Ecology 36: 713-724.

Lyons, J., B. M. Weigel, L. K. Paine \& D. J. Undersander, 2000. Influence of intensive rotational grazing on bank erosion, fish habitat quality, and fish communities in southwestern Wisconsin trout streams. Journal of Soil and Water Conservation 55: 271-276.

Magner, J. A., B. Vondracek \& K. N. Brooks, 2008. Grazed riparian management and stream channel response in southeastern Minnesota (USA) Streams. Environmental Management 42: 377-390.

McCune, B. \& J. B. Grace, 2002. Analysis of Ecological Communities. MjM Software Design, Glenden Beach, Oregon.

McCune, B. \& M. J. Mefford, 1999. PC-ORD. Multivariate Analysis of Ecological Data. Version 5. MjM Software, Glenden Beach, Oregon.

Meehan, W. R. \& W. S. Platts, 1978. Livestock grazing and the aquatic environments. Journal of Soil and Water Conservation 33: 274-278.

Merritt, R. W. \& K. W. Cummins (eds), 1996. An Introduction to the Aquatic Insects of North America, 3rd ed. Kendall/ Hunt, Dubuque, Iowa.

Miltner, R. J., D. White \& C. Yoder, 2004. The biotic integrity of streams and suburbanizing landscapes. Landscapes and Urban Planning 69: 87-100.

MPCA, 2007. MPCA Stream Habitat Assessment (MSHA) Protocol for Stream Monitoring Sites. Minnesota Pollution Control Agency Biological Monitoring Program.

Nerbonne, B. A. \& B. Vondracek, 2001. Effects of local land use on physical habitat, benthic macroinvertebrates, and fish in the Whitewater River, Minnesota, USA. Environmental Management 28: 87-99.

NRCS, 2005. Natural Resources Conservation Service Conservation Practice Standard: Prescribed Grazing, Code 528. NE-T.G. Notice 559. Section IV

Olness, A., S. J. Smith, E. D. Rhoades \& R. G. Mensel, 1975. Nutrient and sediment discharge from agricultural watersheds in Oklahoma. Journal of Environmental Quality 4: 331-336.

Omernik, J. M. \& A. L. Gallant, 1988. Ecoregions of the Upper Midwest States. EPA/600/3-88/037, U.S. EPA. Environmental Research Laboratory, Corvallis, OR: 56.

Owens, L. B., W. M. Edwards \& R. W. Van Keuren, 1996. Sediment losses from a pastured watershed before and 
after stream fencing. Journal of Soil and Water Conservation 51: 90-94.

Pfankuch, D. J., 1975. Stream Reach Inventory and Channel Stability Evaluation. USDA-FS/Northern Region, R1-75002. Government Printing Office \#696-260/200, Washington, DC.

Ranganath, S. C., W. C. Hession \& T. M. Wynn, 2009. Livestock exclusion influences on riparian vegetation, channel morphology, and benthic macroinvertebrate assemblages. Journal of Soil and Water Conservation 64: 33-42.

Rankin, E. T., 1989. The Qualitative Habitat Evaluation Index (QHEI): Rationale Methods, and Application. Division of Water Quality Monitoring \& Assessment, Surface Water Section, Columbus, Ohio.

Richards, C., L. B. Johnson \& G. E. Host, 1996. Landscapescale influences on stream habitats and biota. Canadian Journal of Fisheries and Aquatic Science 53: 295-311.

Rios, S. L. \& R. C. Bailey, 2006. Relationship between riparian vegetation and stream benthic communities at three spatial scales. Hydrobiologia 553: 153-160.

Scrimgeour, G. J. \& S. Kendall, 2003. Effects of livestock grazing on benthic invertebrates from a native grassland ecosystem. Freshwater Biology 48: 347-362.

Simonson, T. D., J. Lyons \& P. D. Kanehl, 1994. Guidelines for evaluating fish habitat in Wisconsin streams. US Forest Service General Technical Report NC-164.

Sovell, L. A., B. Vondracek, J. A. Frost \& K. G. Mumford, 2000. Impacts of rotational grazing and riparian buffers on physicochemical and biological characteristics of southeastern Minnesota, USA, Streams. Environmental Management 26: 629-641.

Sponseller, R. A., E. F. Benfield \& M. Valett, 2001. Relationships between land use, spatial scale and stream macroinvertebrate communities. Freshwater Biology 46: 1409-1424.

StatSoft, Inc., 2009. STATISTICA (data analysis software system), version 9.0. www.statsoft.com.

Stepenuck, K. F., R. L. Crunkilton, M. A. Bozek \& L. Wang, 2008. Comparison of macroinvertebrate-derived stream quality metrics between snag and riffle habitats. Journal of American Water Resources Association 44: 670-678.

Stonehouse, D. P., 1999. Economic evaluation of on-farm conservation practices in the Great Lakes region of North America. Environmetrics 10: 505-520.

Tate, K. W., E. R. Atwill, J. W. Bartolome \& G. Nader, 2006. Significant Escherichia coli attenuation by vegetative buffers on annual grasslands. Journal of Environmental Quality 35: 795-805.

Thorn, W. C., C. S. Anderson, W. E. Lorenzen, D. L. Hendrickson \& J. W. Wagner, 1997. A review of trout management in southeast Minnesota streams. North American Journal of Fisheries Management 17: 860-872.

Trimble, S. W. \& A. C. Mendel, 1995. The cow as a geomorphic agent, a critical review. Geomorphology 13: 233-253.

Undersander, D. J., B. Albert, P. Porter, A. Crossley \& N. Martin, 1993. Pastures for Profit: A Guide to Rotational Grazing. University of Wisconsin-Extension, Madison, Wisconsin. Publications A3529.

Vondracek, B., K. L. Blann, C. B. Cox, J. F. Nerbonne, K. G. Mumford, B. A. Nerbonne, L. A. Sovell \& J. K. Zimmerman, 2005. Land use, spatial scale, and stream systems: lessons from agricultural region. Environmental Management 36: 775-791.

Wang, L. \& P. Kanehl, 2003. Influences of watershed urbanization and instream habitat on macroinvertebrates in cold water streams. Journal of American Water Resources Association 39: 1181-1196.

Wang, L. Z., J. Lyons, P. Kanehl \& R. Bannerman, 2001. Impacts of urbanization on stream habitat and fish across multiple spatial scales. Environmental Management 28: 255-266.

Wang, L. Z., J. Lyons \& P. Kanehl, 2002. Effects of watershed best management practices on habitat and fish in Wisconsin streams. Journal of American Water Resources Association 38: 663-680.

Weigel, B. M., J. Lyons, L. K. Paine, S. I. Dodson \& D. J. Undersander, 2000. Using stream macroinvertebrates to compare riparian land use practices on cattle farms in southwestern Wisconsin. Journal of Freshwater Ecology 15: 93-106.

Wiederholm, T. (ed.), 1986. Chironomidae of the Holarctic region. Keys and diagnoses. Part 2 - Pupae. Entomologica Scandinavica Suppl 28: 1-482.

Wilson, R. S. \& P. L. Bright, 1973. The use of chironomid pupal exuviae for characterizing streams. Freshwater Biology 3: 283-302.

Wilson, R. S. \& L. P. Ruse, 2005. A Guide to the Identification of Genera of Chironomid Pupal Exuviae Occurring in Britain and Ireland (Including Common Genera from Northern Europe) and Their Use in Monitoring Lotic and Lentic Fresh Waters. Special Publication No 13. Freshwater Biological Association, Ambleside, Cumbria, UK.

Zaimes, G. N., R. C. Schultz \& T. M. Isenhart, 2008. Streambank soil and phosphorus losses under different riparian land-uses in Iowa. Journal of the American Water Resources Association 44: 935-947.

Zweig, L. D. \& C. F. Rabeni, 2001. Biomonitoring for deposited sediment using benthic invertebrates: a test on 4 Missouri streams. Journal of North American Benthological Society 20: 643-657. 